\title{
Exploring Employability of Business Graduates: Evidence from Woldia University
}

\author{
Erstu Tarko Kassa ${ }^{1}$ (D)
}

Received: 1 March 2021 / Accepted: 20 November 2021

(c) The Author(s), under exclusive licence to Springer Science+Business Media, LLC, part of Springer Nature 2022

\begin{abstract}
The main purpose of the study is to explore the employability of business graduates through the mediating effect of level of competency with reference to Woldia University business graduates. In this study, a cross-section research design was applied and a quantitative research approach was followed. The data was collected by using questionnaires from the sample of 223 business graduates. The respondents were selected by using the systematic random sampling technique. The collected data were analyzed through descriptive analysis, factor analysis, and path analysis by using SPSS AMOS 23 version. The study finding revealed that exogenous variables of the study have affected the endogenous variable directly and indirectly. Among the variables, university reputation, self-efficacy, and the mediating variable level of competency of graduates affected the employability of business graduates with a statistically significant level $(\mathrm{p}<0.05)$. The path analysis finding indicated that selfefficacy affects the business graduate level of competency with a statistically significant level. On the other hand, English language proficiency affected the business graduates' self-efficacy with a statistically significant level. Finally, the researcher recommends that the higher institution better strive to support its graduates improve their English language skills, enhance their level of competency, and self-efficacy. Besides, building reputation is key for the institution so that its graduates become employees.
\end{abstract}

Keywords Employability $\cdot$ Level of competency $\cdot$ University reputation · Selfefficacy $\cdot$ Business graduates

\section{Introduction}

The current world economy is in the process of change from the old machinebased (industrial age) system to a knowledge-based economic system. This system requires well-equipped manpower to operate an entire business (Alibaygi et al.,

Erstu Tarko Kassa

erstu0910@gmail.com

1 Woldia University, Woldia, Ethiopia 
2013; Pitan \& Atiku, 2017). To supply qualified manpower that fit the twenty-first century requirements, higher education institutions are striving to design their curriculum based on the interest of employers so that their graduates become competent enough in this competitive environment. In that view, higher education institutions are responsible to supply well-equipped and skilled manpower that is able to integrate theory with practical applications (Suarta et al., 2017). However, in the past few decades, due to the emergence of globalization, privatization, and liberalization, the problem of unemployment and under-employment happened around the globe. In 2013, the unemployment rates have doubled due to economic crises, and the employability concept became recognized in nations' labor market policy (Alibaygi et al., 2013; Barba-Sánchez \& Atienza-Sahuquillo, 2017; Gowsalya \& Kumar, 2016; Michael, 2012).

In China, in the past 10 years, young graduates were unable to get employability access which created pressure on the Chinese government. The number of graduates reached 4 million in 2006 to approximately 8.0 million graduates in 2017 (Kiong et al., 2019; Yang et al., 2018).

The problem, which is related to employability, is extremely high in thirdworld countries despite the efforts that development agencies are making to help reduce the challenge for the graduate. In the sub-Saharan African countries, the challenges have increased from time to time (Fenta et al., 2019).

The government of Ethiopia has given more attention to the education sector in the past two decades. As a result, the number of government universities has reached 45, and the higher education enrolment has grown from around 34,000 in 2000 to almost above 300,000 in 2009. Yet, the number of graduates who accessed employment is limited (Semela, 2011). Thus, the government of Ethiopia initiated different programs, especially the youth revolving fund in 2017-2018 to enhance the employability of graduates. Though such programs are interesting opportunities for the graduates, the problem has continued to exist (Ayalew \& Zeleke, 2018).

The challenges that are related to employability in Ethiopia are systematic and difficult to solve within a short period. The factors that became a hindrance are related to the interface or linkage between workers and employers, corruption, and the limited expansion of industries, services, and other sectors.

Some factors affect the employability of graduates. According to Kiong et al. (2019), the English language proficiency, soft skills, self-efficacy (McKenzie \& Schweitzer, 2001), self-confidence (Yang et al., 2016), low level of general economic activity, recession, inflation, rapid changes in technology, disability, willingness to work, and discrimination are the most important factors that affect the employability of graduates (Yenew, 2019).

The previous studies focused on unemployment issues, self-employment, other related issues, and a tad of employability was addressed. However, this study tried to explore the effect of individual factors (level of competency, self-efficacy and English language proficiency) and institutional factor (University reputation) on the employability of business graduates. 


\section{Literature Review}

\section{Employability}

Employability is used by different authors interchangeably with the concept of workreadiness. It is a set of skills that helps to access a job (Rowe \& Zegwaad, 2017). According to Bhola and Dhanawade (2013), "Employability is the ability to move from unemployment to employment." Recently, employability has become a buzzword (Hillage \& Pollard, 1998).

Hillage and Pollard (as cited by Gedye \& Beaumont, 2018) defined employability as the ability to gain initial employment, to meet new job requirements within the same organization, and the quality of work or employment. Generally, employability has been defined as the ability to gain initial employment after graduation or to change to a new position within an organization and secure the best and interesting work to attain the personal goal (Pheko \& Molefhe, 2017).

Education can be delivered through formal learning, non-formal learning, and informal learning. Formal learning is institutionalized, intentional, and prearranged through a public organization (Kiong et al., 2019).

Among the different factors, education plays a significant role in employability. Its effect is measured by the academic performance of students and its role in increasing satisfaction for them (Caballero et al., 2017). According to Juhdi et al. (2010), higher level of education and extended occupation are expected to have a positive impact on employability, that is to say, employees that have long years of education can find suitable jobs easily. However, Tymon (as cited by Harry et al., 2018) argues that higher education alone is not a guarantee of a high-paying job, but it enhances employability. Employability is, thus, a multifaceted concept having both internal and external facets (Hooley \& Grant, 2017). Nonetheless, it is essential to focus on individual perceptions, which are influenced by both internal and external facets (Anas \& Hamzah, 2017; Rothwell \& Arnold, 2007).

\section{Work Readiness}

Scholars argued that the word work-readiness appears to lack clear definition and consensus. There are different terms such as "employability," "preparedness," and "transferable skills" used interchangeably with work readiness (Caballero et al., 2011).

Apart from the many possible definitions, work readiness is attributed to any effort made to enhance the strength of individuals with knowledge, skills, attitudes, and values. Hence, it is the process of developing the level of mental, physical, social, and emotional growth (Winkel \& Sri Hastuti, 2004; Hamalik, 2008). In other words, it is simply about possessing skills, knowledge, attitudes, and commercial understanding that will help graduates to be productive (Mason et al., 2009). Generally, work readiness includes motivation, maturity, personal growth/development, organizational awareness, technical focus, interpersonal orientation, attitudes to work, problem-solving, adaptability, and resilience (Caballero et al., 2011). 
Work readiness may be influenced by numerous factors such as physical, mental, and emotional conditions; needs; motives; goals; skills; knowledge; and understanding learned which has positive influence (Slameto, 2010). According to Fitriyanto (2006), the characteristics of students who already have work readiness include having logical and objective consideration, the ability and willingness to work with others, the ability to control themselves or emotions, the courage to accept responsibility individually, and the ability to adapt to the environment and technological developments.

Finally, work readiness and employability are the same or used interchangeably though. Yorke (2010) clearly states that work readiness is a set of circumstances helpful for having a job for the first time, while employability is a skill that enables job seekers to gain employment. The graduates need to have both employability and work-readiness to increase their chance of employment (Sachs et al., 2017; Caballero \& Walker, 2010). On the other hand, Herbert et al. (2020) state that work readiness is being capable of doing a job properly without the influence of others within a short period.

To conclude, work readiness is the ability of workers and job seekers to undertake a given task adequately, while employability is a skill that helps them to search for new jobs and a means to access the jobs.

\section{Factors Affecting Employability of Graduates}

The first factor that determines the employability of job seekers is university reputation. Employers are mostly influenced by graduates who graduated from the most reputable and high-ranking universities. Graduates from reputable universities build more social and cultural capital, yet less for graduates from less reputable universities (Qenani et al., 2014). Field of study, credibility, specialization, and center of excellence of the university can be factors which determine the employability of graduates (Harry et al., 2018). The employees from reputable universities can bring a competitive advantage for the employers by converting theoretical knowledge to practical skills; they can increase trust and credibility for the organization (Bano \& Vasantha, 2019). Based on the above discussion the hypothesis would be:

$\mathrm{H}_{1}$ : University Reputation Has a Positive Statistically Significant Effect on the Employability of Business Graduates

The second factor that determines the employability of graduates is the level of competency. It includes functional in assorted working environments; interpersonal communication skills; mutual understanding; energy and passion of the graduates; flexibility; responsibility; leadership and influence; seriousness; self-confidence; cultural intelligence; ability to collect, organize, and analyze data; lifelong learning; vocational ethics; participation as a team member; decision-making; problemsolving; written and oral communication; critical thinking; information literacy; computer literacy; understanding international issues; creative thinking; and English language skills (Alibaygi et al., 2013). According to Caballero et al. (2017), to say the worker is competent; he should fulfill the knowledge, values, attitudes, abilities, 
and skills required to obtain, keep, and perform well in a job (De Guzman \& Choi, 2013). In this competitive world, employers required skills and knowledge: they need an employee who is able to convert theoretical knowledge to practical implementations. Thus, competency has a positive effect on the employability of university graduates (Rule, 2011). This discussion would lead us to identify the following hypothesis;

$\mathrm{H}_{2}$ : Level of Competency Has a positive Statistical Significant Effect on the Employability of Business Graduates

The other factor that affects the employability of graduates is self-efficacy. It is a belief in one's ability to succeed in a particular situation. As cited by Chow et al. (2019), Bandura (1986) defined the word self-efficacy as the ability to perform tasks shortly and efficiently in certain activities. Individual self-efficacy beliefs come from four important sources such as mastery experience, vicarious experience, social persuasion, and diversity receptivity. Self-efficacy also means the ability to achieve goals easily, face challenges, get jobs easily, and understand task easily (Darlington \& Scott, 2002).

To improve the self-efficacy of graduates, the support from most important actors such as friends, families, and other social groups is essential and helps graduates to search for a job. When they develop self-efficacy, they become self-confident and motivated to convince the employers (Caballero et al., 2017). Thus, there is a positive relationship between self-efficacy and enhanced competency of students and the employability of graduates (Ahmed et al., 2019; Zhong et al., 2020). Accordingly, the above discussion helps us to develop the following hypothesis:

$\mathrm{H}_{3}$ : Self-Efficacy Has a Positive Statistically Significant Effect on the Employability of Business Graduates

$\mathrm{H}_{4}$ : Self-Efficacy Has a Positive Statistically Significant Effect on the Graduate Level of Competency of Business Graduates

The last factor investigated in this study and that affected the employability of graduates is English language proficiency. Communication happens in every movement of human beings. In terms of communicating easily with friends, families, and employers, language is the most important tool. Employers require an employee who communicates easily with others and are fluent in the international language, "English." A graduate who has good communication skill becomes a favorite employee for an organization (Suarta et al., 2017). El Mansour and Dean (2016) and Rivera et al. (as cited by Karli, 2016) stated that communicating in a foreign language is perceived as an employability skill both by university faculty and employers of human resource development fields.

Some researchers suggest that English proficiency might influence a person's self-efficacy (McKenzie \& Schweitzer, 2001) and self-confidence (Yang et al., 2016) in his/her education or learning process and psychological adjustment to an Englishspeaking environment in university as well as the workplace. English proficiency might be a key factor, which directly and indirectly influences graduate performance 
in academic as well as employment ability (Kiong et al., 2019). Based on the above discussion, the researcher proposed the following hypotheses.

$\mathrm{H}_{5}$ : English Language Proficiency Has a Positive Statistically Significant Effect on the Self-Efficacy of Business Graduates

$\mathrm{H}_{6}$ : English Language Proficiency Has a Positive Statistically Significant Effect on the Employability of Business Graduates

\section{Materials and Methods}

\section{Research Design}

To undertake this study, the researcher used a cross-sectional research design. This design is crucial to collect data from one shot of time from the identified respondents. Regarding to research approaches, the researcher followed quantitative research approach because the collected data was numeric.

\section{Target Population and Sampling Techniques}

The target population of this study were 2785 students who graduated from Woldia University in 2020-2021. In the stated period, the university has graduated students who studied under one institute, 2 colleges, 4 faculties, and one school. The researcher selected the faculty of business and economics graduates purposely, because the study focused on to explore the employability of business graduates in the university. In this faculty, 620 students have graduated in the year 2020-2021. Therefore, the target population were both regular and extension (weekend) bachelor degree business graduates of the faculty of business and economics. The detail of the target population is described as follows in Table 1.

To select respondents for this study from the target population of the study, the researcher used systematic random sampling techniques. This sampling technique allows equal chance for all target population to participate in this study. The sample size was also determined by using Yamane (1967) formula and proportional technique from each business type. Thus, the formula is described as follows:

Table 1 Target population

\begin{tabular}{lll}
\hline S/n & Departments & $\begin{array}{l}\text { Number of } \\
\text { graduates }\end{array}$ \\
\hline 1 & Accounting and finance & 265 \\
2 & Economics & 88 \\
3 & Management & 267 \\
4 & Total & 620 \\
\hline
\end{tabular}

Source: Faculty of business and economics registrar coordinator, (2020) 


$$
n=\frac{N}{1+N(e)^{2}}
$$

where $N=$ target population, $n=$ sample size, and $e=$ error term

$$
\begin{gathered}
n=\frac{620}{1+620(0.05)^{2}} \\
n=243
\end{gathered}
$$

Based on the above sample size, 104 accounting and finance, 105 management, and 34 economics major graduates have participated.

\section{Data Collection Instruments}

Regarding data collection instruments, 6 items for university reputation, 9 items for level of competency, and 10 items for employability were adapted from Alibaygi et al. (2013). Six items for self-efficacy were adapted from Darlington and Scott (2002), and the remaining study variable, English language proficiency had 6 items which were adapted from Singh and Singh (2008). The data were collected by a total of 37 items measured by Likert scale items ranging from strongly disagree to strongly agree level. The measurement ranged from 1 up to $5(1=$ strongly disagree, $2=$ disagree, $3=$ neutral, $4=$ agree, and $5=$ strongly agree). However, after conducting factor analysis, 2 items from English language proficiency and 3 items from the level of competency have been removed due to low factor loading which is below 0.5 . Therefore, the analysis was conducted by the data collected with only 32 items.

\section{Methods of Data Analysis}

The collected data were analyzed by using descriptive statistics, factor analysis, and path analysis. The software utilized in this study were SPSS version 25 for descriptive and factor analysis and SPSS AMOS 23 version for path analysis.

\section{Results and Discussions}

\section{Response Rate}

From the total dispatched 243 questionnaires, 223 were returned. The remaining 20 questionnaires were not utilized for analysis purpose of which 15 were disqualified and 5 were not returned by respondents. The total response rate was, thus, $89.92 \%$. 


\section{Demographic Variables Analysis}

From the total population, $35.9 \%$ were female and the remaining $64.1 \%$ were male. The respondents' age category in Table 2 shows that $43.5 \%$ of the respondents were between the age of 20 and 25 years and $43.5 \%$ between 25 and 30 years, and the remaining were categorized under the age of above 30 years.

\section{Statistical Tests of the Study Variables}

\section{Reliability Statistics Test}

The Cronbach's Alpha result in Table 3 indicates that all items with respective variables were above the cutoff point 0.7 set by Julie (2007). The Cronbach's Alpha value of English language proficiency, university reputation, level of competency, self-efficacy, and the dependent variable employability of business graduates were $0.921,0.862,0.905,0.946$, and 0.936 , respectively. The overall value of the 32 items was 0.923 . This result occurred to be evidence for further analysis in the study.

\section{Multicollinearity Test}

The result of variance inflation factor (VIF) of each independent variable is below 4.0, as shown in Table 4. The VIF result is 1.147 for ELP, 1.079 for UR, 1.371 for LC, and 1.279 for SE. Therefore, the result is an evidence that there is no multicollinearity problem within independent variables of the study because the VIF value of each independent variable is below the cutoff point of 4.0 which is set by different researchers.

\section{Factor Analysis of the Study Variables}

After conducting the factor analysis, the following items were removed. Among the variable English language proficiency, items ELP5 and ELP6 have been removed during the analysis, and from the level of competency items, LC13, LC14, and

Table 2 Demographic variables

\begin{tabular}{lllrrr}
\hline Variables & & Frequency & Percent & Valid percent & $\begin{array}{l}\text { Cumulative } \\
\text { percent }\end{array}$ \\
\hline \multirow{2}{*}{ Gender } & Male & 143 & 64.1 & 64.1 & 64.1 \\
& Female & 80 & 35.9 & 35.9 & 100.0 \\
& Total & 223 & 100.0 & 100.0 & \\
\multirow{2}{*}{ Age } & $20-25$ & 97 & 43.5 & 43.5 & 43.5 \\
& $25-30$ & 97 & 43.5 & 43.5 & 87.0 \\
& Above 30 & 29 & 13.0 & 13.0 & 100.0 \\
& Total & 223 & 100.0 & 100.0 & \\
\hline
\end{tabular}

Source: survey result, (2020) 
Table 3 Reliability statistics

\begin{tabular}{lll}
\hline Variables & N of Items & Cronbach's Alpha \\
\hline English language proficiency & 4 & 0.921 \\
University reputation & 6 & 0.862 \\
Level of competency & 6 & 0.905 \\
Self-efficacy & 6 & 0.946 \\
Employability of business graduates & 10 & 0.936 \\
Total Items & 32 & 0.923 \\
\hline
\end{tabular}

Source: survey result, (2020)

LC15 have been removed due to the low value of the load below 0.5. Based on this, the factor analysis is presented as follows:

\section{KMO and Bartlett's Test}

The estimate in the first row is the result of the KMO test shown in Table 5. The value, 0.875 , is a sign that helps to conduct factor analysis and can be taken as an evidence for factor analysis. The estimate in the last row result from Bartlett's Test is significant.

The communal result, in Table 6, of all extracted items was above the cutoff point of 0.5 . This result is helpful to analyze the study variables. From the total 37 items, 2 items were removed from the variable of English language proficiency and 3 items from the level of competency due to a low value of the loading which is below 0.5 . Therefore, the data became ready for further analysis and to examine the effect of each variable with respect to and against the endogenous variable. Besides, the exogenous variables have been examined properly after verifying the quality of the data.

As shown in Table 7, the eigenvalue of each of the total five components was above 1 . The eigenvalue of the first component was 9.855, of the second component was 4.178 , of the third component was 3.690, of the fourth component was 2.653, and the remaining fifth-factor's eigenvalue was 2.295. The first component explained a variance by $30.798 \%$, the second component' variance was explained by $13.057 \%$, the third component's variance was explained by $11.53 \%$, the fourth component's variance was explained by $8.291 \%$, and the fifth component's variance was explained by $7.173 \%$. The cumulative variance explained by the variables is 70.849 .

The pattern in Table 8 shows the loadings of the items, with ten items loading above 0.5 levelled on component 1,6 items on component 2, 6 items on component 3,6 items on component 4 , and the remaining 4 items were levelled on component 5 . The loading of all the items was above 0.5 . Hence, this result can be a confirmation for further analysis of the study such as path analysis, regression, and others. 
Table 4 Collinearity statistics

\begin{tabular}{lll}
\hline Variables & Tolerance & VIF \\
\hline English Language Proficiency (ELP) & 0.872 & 1.147 \\
University Reputation (UR) & 0.926 & 1.079 \\
Level of Competency (LC) & 0.730 & 1.371 \\
Self-efficacy (SE) & 0.782 & 1.279 \\
\hline
\end{tabular}

Source: survey result, (2020)

\section{Effect Analysis of Variables and Hypothesis Testing}

As it is shown in Table 9, university reputation had a statistically significant effect on the employability of business graduates with the coefficients of 0.185 and a significance $p$ value of 0.007 . Therefore, the proposed hypothesis-university reputation has a positive statistically significant effect on the employability of business graduateshas been accepted. This effect is a direct effect on the employability of graduates. The other exogenous variables that directly affected the employability of business graduates was self-efficacy with the coefficient of 0.146 and a significant $p$ value $(p=0.006)$. Thus, the hypothesis that self-efficacy has a positive statistically significant effect on the employability of business graduates has been accepted because it had a positive statistical significant effect on the employability of graduates. Graduate-level competency has a positive significant effect on the employability of graduates. The statistical result in Table 9 shows that the level of competency affected employability of the graduates by the coefficient of 0.188 with a high significant $p$ value $(p=0.00)$. This result is a shred of evidence that supported the proposed hypothesis-level of competency has a positive statistically significant effect on the employability of business graduates.

The other hypothesis-self-efficacy has a positive statistically significant effect on the level of competency for business graduates-has been accepted. This is supported by the regression result shown in Table 9 that self-efficacy affected the graduate level of competency by the coefficient of 0.445 with a high significant $p$ value $(p=0.000)$. Similarly, the graduate self-efficacy was affected by the English language proficiency of graduates by coefficient 0.215 with a significant $p$-value $(p=0.003)$. Therefore, the proposed hypothesis-English language proficiency has a positive statistically significant effect on the self-efficacy of business graduateshas been accepted. The last hypothesis-English language proficiency has a positive statistically significant effect on the employability of business graduates-has been rejected, for the coefficient result in Table 9 indicated a $p$-value $(p=0.243)$ which is not significant (Figs. 1 and 2).

Table 5 KMO and Bartlett's test

\begin{tabular}{lll}
\hline Kaiser-Meyer-Olkin Measure of Sampling Adequacy & 0.875 \\
\hline Bartlett's Test of Sphericity & Approx. Chi- & 5781.049 \\
& Square & \\
& Df & 496 \\
Sig & 0.000 \\
\hline
\end{tabular}

Source: survey result, (2020) 
Table 6 Communalities

\begin{tabular}{|c|c|c|}
\hline Items & Initial & Extraction \\
\hline ELP1 & 1.000 & 0.839 \\
\hline ELP2 & 1.000 & 0.790 \\
\hline ELP3 & 1.000 & 0.814 \\
\hline ELP4 & 1.000 & 0.780 \\
\hline UR7 & 1.000 & 0.627 \\
\hline UR8 & 1.000 & 0.642 \\
\hline UR9 & 1.000 & 0.705 \\
\hline UR10 & 1.000 & 0.724 \\
\hline UR11 & 1.000 & 0.660 \\
\hline UR12 & 1.000 & 0.600 \\
\hline LC16 & 1.000 & 0.597 \\
\hline LC17 & 1.000 & 0.796 \\
\hline LC18 & 1.000 & 0.590 \\
\hline LC19 & 1.000 & 0.794 \\
\hline LC20 & 1.000 & 0.736 \\
\hline LC21 & 1.000 & 0.643 \\
\hline SE22 & 1.000 & 0.705 \\
\hline SE23 & 1.000 & 0.825 \\
\hline SE24 & 1.000 & 0.840 \\
\hline SE25 & 1.000 & 0.820 \\
\hline SE26 & 1.000 & 0.773 \\
\hline SE27 & 1.000 & 0.792 \\
\hline EMP28 & 1.000 & 0.664 \\
\hline EMP29 & 1.000 & 0.580 \\
\hline EMP30 & 1.000 & 0.662 \\
\hline EMP31 & 1.000 & 0.691 \\
\hline EMP32 & 1.000 & 0.658 \\
\hline EMP33 & 1.000 & 0.669 \\
\hline EMP34 & 1.000 & 0.696 \\
\hline EMP35 & 1.000 & 0.684 \\
\hline EMP36 & 1.000 & 0.684 \\
\hline EMP37 & 1.000 & 0.591 \\
\hline
\end{tabular}

Extraction Method: Principal Component Analysis

Source: survey result, (2020)

\section{Discussions}

Literatures indicate that graduates should develop job searching and employability skills and stakeholders should remove barriers that become a hindrance for graduates' employability. It is known that the employability of graduates is affected by different factors. In this study, only four factors were considered and analyzed based on the collected data. From the identified variables, two factors, namely, university reputation and self-efficacy, affected the employability of graduates directly. It 
Table 7 Total variance explained

\begin{tabular}{|c|c|c|c|c|c|c|c|}
\hline \multirow[t]{2}{*}{ Component } & \multicolumn{3}{|c|}{ Initial eigenvalues } & \multicolumn{3}{|c|}{$\begin{array}{l}\text { Extraction sums of squared } \\
\text { loadings }\end{array}$} & \multirow{2}{*}{$\begin{array}{l}\text { Rotation Sums } \\
\text { of Squared } \\
\text { Loadings }^{\mathrm{a}} \\
\text { Total }\end{array}$} \\
\hline & Total & $\begin{array}{l}\% \text { of } \\
\text { Variance }\end{array}$ & $\begin{array}{l}\text { Cumulative } \\
\%\end{array}$ & Total & $\begin{array}{l}\% \text { of } \\
\text { Variance }\end{array}$ & $\begin{array}{l}\text { Cumulative } \\
\%\end{array}$ & \\
\hline 1 & 9.855 & 30.798 & 30.798 & 9.855 & 30.798 & 30.798 & 7.755 \\
\hline 2 & 4.178 & 13.057 & 43.856 & 4.178 & 13.057 & 43.856 & 6.591 \\
\hline 3 & 3.690 & 11.530 & 55.386 & 3.690 & 11.530 & 55.386 & 6.391 \\
\hline 4 & 2.653 & 8.291 & 63.676 & 2.653 & 8.291 & 63.676 & 4.338 \\
\hline 5 & 2.295 & 7.173 & 70.849 & 2.295 & 7.173 & 70.849 & 4.414 \\
\hline 6 & 0.915 & 2.860 & 73.709 & & & & \\
\hline 7 & 0.813 & 2.540 & 76.249 & & & & \\
\hline 8 & 0.742 & 2.318 & 78.567 & & & & \\
\hline 9 & 0.635 & 1.983 & 80.550 & & & & \\
\hline 10 & 0.615 & 1.922 & 82.472 & & & & \\
\hline 11 & 0.521 & 1.627 & 84.098 & & & & \\
\hline 12 & 0.507 & 1.584 & 85.683 & & & & \\
\hline 13 & 0.433 & 1.353 & 87.035 & & & & \\
\hline 14 & 0.374 & 1.168 & 88.203 & & & & \\
\hline 15 & 0.362 & 1.133 & 89.335 & & & & \\
\hline 16 & 0.339 & 1.058 & 90.393 & & & & \\
\hline 17 & 0.325 & 1.015 & 91.408 & & & & \\
\hline 18 & 0.304 & 0.949 & 92.358 & & & & \\
\hline 19 & 0.283 & 0.885 & 93.243 & & & & \\
\hline 20 & 0.263 & 0.821 & 94.064 & & & & \\
\hline 21 & 0.221 & 0.692 & 94.755 & & & & \\
\hline 22 & 0.218 & 0.681 & 95.437 & & & & \\
\hline 23 & 0.202 & 0.631 & 96.068 & & & & \\
\hline 24 & 0.191 & 0.598 & 96.666 & & & & \\
\hline 25 & 0.177 & 0.554 & 97.219 & & & & \\
\hline 26 & 0.162 & 0.506 & 97.725 & & & & \\
\hline 27 & 0.149 & 0.466 & 98.191 & & & & \\
\hline 28 & 0.145 & 0.452 & 98.643 & & & & \\
\hline 29 & 0.130 & 0.405 & 99.048 & & & & \\
\hline 30 & 0.111 & 0.348 & 99.396 & & & & \\
\hline 31 & 0.104 & 0.326 & 99.722 & & & & \\
\hline 32 & 0.089 & 0.278 & 100.000 & & & & \\
\hline
\end{tabular}

Extraction method: principal component analysis

Source: survey result, (2020)

${ }^{a}$ When components are correlated, sums of squared loadings cannot be added to obtain a total variance 
Table 8 Pattern matrix

\begin{tabular}{|c|c|c|c|c|c|}
\hline \multirow[t]{2}{*}{ Items } & \multicolumn{5}{|c|}{ Component } \\
\hline & 1 & 2 & 3 & 4 & 5 \\
\hline EMP34 & 0.889 & & & & \\
\hline EMP31 & 0.858 & & & & \\
\hline EMP32 & 0.847 & & & & \\
\hline EMP35 & 0.840 & & & & \\
\hline EMP33 & 0.824 & & & & \\
\hline EMP36 & 0.757 & & & & \\
\hline EMP30 & 0.747 & & & & \\
\hline EMP37 & 0.725 & & & & \\
\hline EMP29 & 0.716 & & & & \\
\hline EMP28 & 0.709 & & & & \\
\hline SE23 & & 0.926 & & & \\
\hline SE24 & & 0.910 & & & \\
\hline SE25 & & 0.902 & & & \\
\hline SE26 & & 0.898 & & & \\
\hline SE27 & & 0.871 & & & \\
\hline SE22 & & 0.816 & & & \\
\hline LC20 & & & 0.899 & & \\
\hline LC17 & & & 0.833 & & \\
\hline LC18 & & & 0.831 & & \\
\hline LC19 & & & 0.826 & & \\
\hline LC16 & & & 0.800 & & \\
\hline LC21 & & & 0.704 & & \\
\hline UR9 & & & & 0.853 & \\
\hline UR11 & & & & 0.837 & \\
\hline UR10 & & & & 0.829 & \\
\hline UR12 & & & & 0.737 & \\
\hline UR8 & & & & 0.711 & \\
\hline UR7 & & & & 0.639 & \\
\hline ELP4 & & & & & 0.906 \\
\hline ELP2 & & & & & 0.898 \\
\hline ELP3 & & & & & 0.881 \\
\hline ELP1 & & & & & 0.873 \\
\hline
\end{tabular}

Extraction method: principal component analysis

Rotation Method: Promax with Kaiser Normalization

Source: survey result, (2020)

${ }^{\text {a}}$ Rotation converged in 6 iterations

meant that UR and SE affected the employability of graduates by coefficients 0.185 and 0.146 , respectively. The self-efficacy of graduates helps to search new jobs and win the competition among applicants in an organization, and university reputation may motivate an employer to select and recruit among the candidates. This result is supported by the findings of Qenani et al. (2014) and Harry et al. (2018). 
Table 9 Regression weights

\begin{tabular}{llllllll}
\hline \multicolumn{2}{l}{ Variables effect } & & Estimate & S.E & C.R & $\begin{array}{l}\text { Standardized } \\
\text { regression }\end{array}$ & P \\
\cline { 1 - 3 } SE & $<-$ & ELP & 0.215 & 0.071 & 3.014 & 0.198 & 0.003 \\
\hline LC & $<-$ & SE & 0.445 & 0.057 & 7.751 & 0.462 & 0.00 \\
EMP & $<--$ & ELP & 0.061 & 0.052 & 1.168 & 0.074 & 0.243 \\
EMP & $<--$ & LC & 0.188 & 0.054 & 3.498 & 0.238 & 0.00 \\
EMP & $<--$ & UR & 0.185 & 0.068 & 2.715 & 0.169 & 0.007 \\
EMP & $<--$ & SE & 0.146 & 0.053 & 2.772 & 0.192 & 0.006 \\
\hline
\end{tabular}

Source: survey result, (2020)

Another path or direction is an indirect path that affected the employability of graduate through the mediating effect of level of competency and self-efficacy, which means that ELP affected SE of graduates on a statistically significant level (McKenzie \& Schweitzer, 2001) and then ELP and SE of graduates jointly affected the graduate level of competency. Finally ELP, SE, and LC of graduates affected the employability of graduates. This finding is supported by the findings of El Mansour and Dean (2016), Burgaz (2008), Rivera et al. (2012), and Rule (2011). Among the exogenous variables, self-efficacy has affected the endogenous variable directly and indirectly. The variable's indirect effect passes through the level of competency, finally affecting the employability of graduates (Ahmed et al., 2019; Zhong et al., 2020). The second path has directly affected the employability of graduates with the coefficient of 0.146 and a statistically significant $p$ value $=0.006$ (Caballero et al., 2017; Ahmed et al., 2019; Zhong et al., 2020).

This study tried to explore the employability of graduates by assessing crucial factors that may have direct and indirect effect on it. This study also indicates the employers on which factor they need to focus to recruit the graduates. As it is shown in the analysis section above, the identified variables significantly affected the employability of graduates directly and indirectly. Especially, the mediating variable was directly affected by self-efficacy and indirectly influenced by graduates' English language proficiency. Hence, we can understand that the graduates should strive to

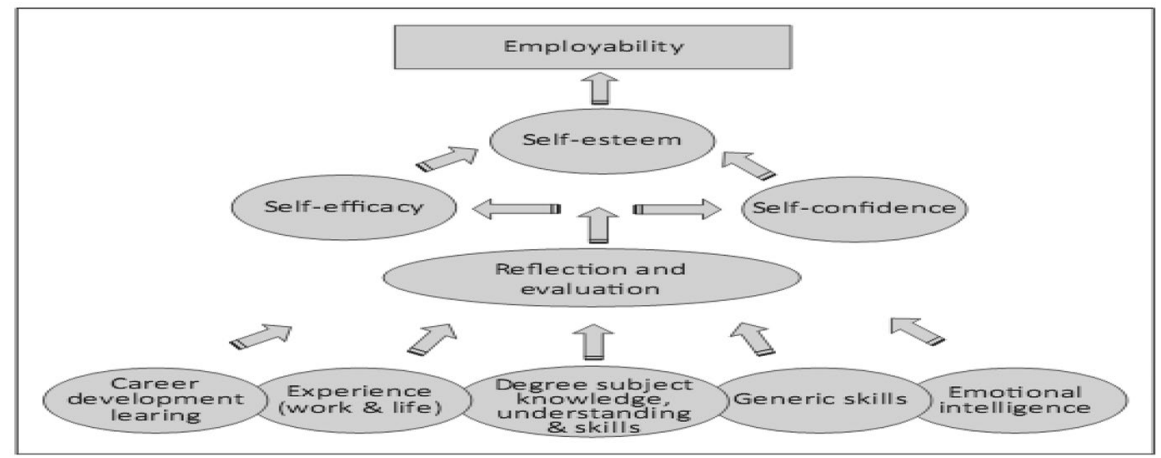

Source: Dacre Pool, L... \& Sewell, P. (2007). The key to employability: Developing a practical model of graduate employability

Fig. 1 Factors affecting employability 


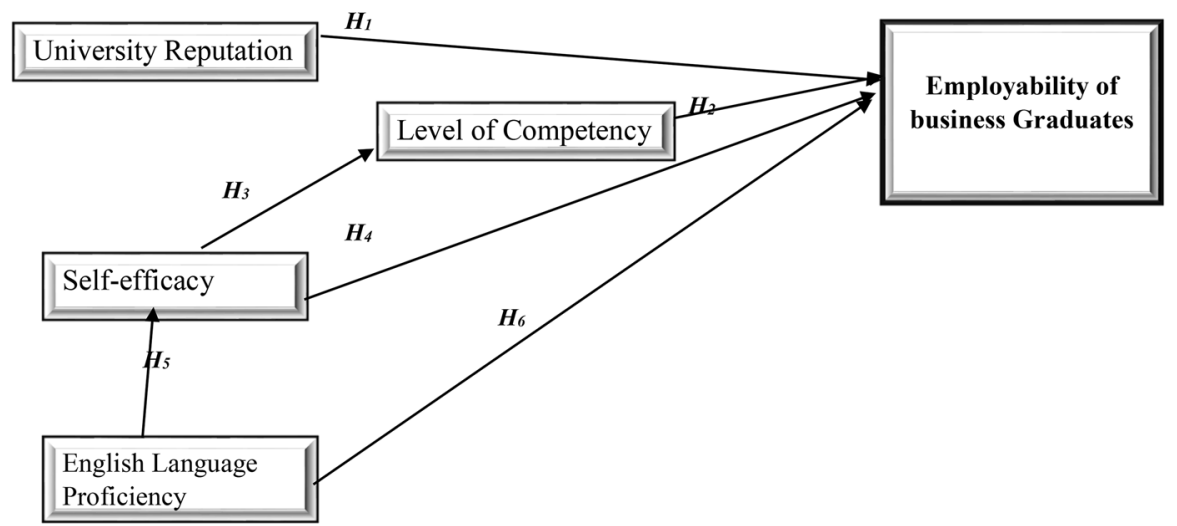

Fig. 2 Conceptual framework of the study

improve their English language skills and enhance their self-efficacy to improve the level of competency and then to access appropriate jobs.

To conclude, university reputation and self-efficacy had a direct effect on the endogenous variable, and English language proficiency, self-efficacy, and level of competency affected the endogenous variable both directly and indirectly.

\section{Conclusions}

Employability is the ability to move from unemployment to employment, and it has become a buzzword these days (Hillage \& Pollard, 1998). In Ethiopia, to get initial job, university graduates face different challenges such as the absence of a job, lack of job searching skills, equity, corruption, unfair competition, and others. This study primarily focused on the factors that affect the employability of business graduates and emphasized on the mediating variables. Based on the analysis and discussions, the following conclusion has been drawn. English language proficiency has not significantly affected the employability of business graduates; however, it had an indirect effect through self-efficacy and level of competency.

University reputation had a statistically significant effect on the employability of business graduates. The exogenous variable, self-efficacy, affected the employability of business graduates directly and indirectly. The direct effect was statistically significant, and the indirect effect was indicated through the path of the level of competency. Self-efficacy had a statistically significant effect on the mediating variable of the level of competency, and the employability of business graduates was indirectly affected by self-efficacy, and finally level of competency had a statistical significant effect on the employability of business graduates. Based on the finding, the researcher recommends that the higher institution better strive to support its graduates to improve their English language skills, level of competency, and self-efficacy. In addition, building reputation is key for the institution so that its graduates become employees. 


\section{Limitation and Future Directions of the Research}

The limitations of study were that:

- The study addressed only one university, personal, and university-related factors.

The future directions of the research will be on:

- Conducting a comparative analysis among graduates of different universities, colleges, and departments

- Other factors such as political, cultural, social, technological, curriculumrelated factors, COVID-19-related factors, and economic factors that may affect employability of graduates should be considered.

Abbreviations ELP: English language proficiency; UR: University reputation; LC: Level of competency; SE: Self-efficacy; EMP: Employability

Acknowledgements I am grateful to all anonymous reviewers, my respondents, Tilahun G. and Tesfay (Woldia University) and Solomon Girma for editing the article on time.

Authors' Contributions The research is done independently. I have carried out the whole work of the study.

Funding The author has not received a fund from any organization.

Availability of Data and Materials All data are included in the manuscript and available on hand too.

\section{Declarations}

Ethics Approval and Consent to Participate The respondents have agreed before filling the questionnaires and the concerned department wrote a letter to collect a data.

Consent for Publication The researcher agreed to publish in the journal.

Competing Interests The authors declare no competing interests.

\section{References}

Ahmed, H., Nawaz, S., \& Rasheed, M. I. (2019). Self-efficacy, Self-esteem, and Career Success: The Role of Perceived Employability. Journal of Management Sciences, 6(2), 18-32. https://doi.org/10. 20547/jms.2014.1906202

Alibaygi, A. H., Barani, S., Karami, E., \& Pouya, M. (2013). Employability determinants of senior agricultural students in Iran. Journal of Agricultural Science and Technology, 15(4), 673-683.

Anas, I., \& Hamzah, S. R. A. (2017). Conceptual study on the enhancement of employability among undergraduates in work based learning setting. International Journal of Academic Research in Business and Social Sciences, 7(4), 65-79. 
Ayalew, M. M., \& Zeleke, S. A. (2018). Modeling the impact of entrepreneurial attitude on selfemployment intention among engineering students in Ethiopia. Journal of Innovation and Entrepreneurship, 7(1), 1-27.https://doi.org/10.1186/s13731-018-0088

Bandura, A. (2010). Self-efficacy. The Corsini Encyclopedia of Psychology pp 1-3.

Bano, Y., \& Vasantha, S. (2019). Influence of university reputation on employability. International Journal of Scientific \& Technology Research, 8(11), 2061-2064.

Barba-Sánchez, V., \& Atienza-Sahuquillo, C. (2017). Entrepreneurial motivation and self-employment: Evidence from expectancy theory. International Entrepreneurship and Management Journal, 13(4), 1097-1115.

Bhola, S. S., \& Dhanawade, S. (2013). Higher education and employability-A review. Available at SSRN 2290103.

Burgaz, B. (2008). Employability Competences of Vocational Secondary School Students. Eurasian Journal of Educational Research (EJER), (31).

Caballero, G., Álvarez, P., \& López-Miguens M. J. (2017). Internal determinants of university student employability Construction and validation of scales. 3rd International Conference on Higher Education Advances, HEAd'17. Valencia. https://doi.org/10.4995/HEAd17.2017.5491

Caballero, C., \& Walker, A. (2010). Work readiness in graduate recruitment and selection: A review of current assessment methods. Journal of Teaching and Learning for Graduate Employability, 1(1), $13-25$.

Caballero, C., Walker, A., \& Fuller-Tyszkiewicz, M. (2011). The Work Readiness Scale (WRS): Developing a measure to assess work readiness in college graduates. Journal of Teaching and Learning for Graduate Employability, 2(2), 41-54.

Chow, H. J., Wong, S. C., \& Lim, C. S. (2019). Examining Mediating Role of Self-Efficacy on undergraduates' Perceived Employability. International Journal of Academic Research Business and Social Sciences, 9(6), 135-158.

Darlington, Y., \& Scott, D. (2002). Qualitative research in practice; stories from the field. Open University Press.

De Guzman, A. B., \& Choi, K. O. (2013). The relations of employability skills to career adaptability among technical school students. Journal of Vocational Behavior., 82(3), 199-207.

El Mansour, B., \& Dean, J. C. (2016). Employability skills as perceived by employers and university faculty in the field of human resource development (HRD) for entry level graduate jobs. Journal of Human Resource and Sustainability Studies, 4(10), 39.

Fenta, H. M., Asnakew, Z. S., Debele, P. K., Nigatu, S. T., \& Muhaba, A. M. (2019). Analysis of supply side factors influencing employability of new graduates: A tracer study of Bahir Dar University graduates. Journal of Teaching and Learning for Graduate Employability, 10(2), 67-85.

Fitriyanto, A. (2006). Ketidakpastian Memasuki Dunia Kerja Karena Pendidikan. Jakarta: Dineka Cipta.

Gedye, S., \& Emily Beaumont, E. (2018). The ability to get a job: student understandings and definitions of employability. Education + Training (Emerald Publishing Limited) 60(5), 406-420. https://doi. org/10.1108/ET-10-2017-0159

Gowsalya, G., \& Kumar, A. (2016). A study on the factors affecting employability skills among college students in Namakkal District of Tamil Nadu. International Journal of Commerce and Management Research, ISSN, 2455-1627.

Singh, G. K. G., \& Singh, S. K. G. (2008). Malaysian Graduates' Employability Skills. Unitar E-Journal, $14-44$.

Hamalik, O. (2008). Perencanaan pembelajaran berdasarkan pendekatan sistem. Jakarta: Bumi Aksara.

Harry, T., Chinyamurindi, W. T., \& Mjoli, T. (2018). Perceptions of factors that affect employability amongst a sample of final-year students at a rural South African university. SA Journal of Industrial Psychology/SA Tydskrif vir Bedryfsielkunde, 44(0), a1510. https://doi.org/10.4102/sajip.v44i0.1510

Hillage, J., \& Pollard, E. (1998), "Employability: developing a framework for policy analysis", Research Briefing No. 85, Department for Education and Employment, London.

Hooley, T., \& Grant,K. (2017). Graduate Career Handbook.

Herbert, I. P., Rothwell, A. T., Glover, J. L., \& Lambert, S. A. (2020). Graduate employability, employment prospects and work-readiness in the changing field of professional work: Article 100378. The International Journal of Management Education, 18(2), 1-13.

Juhdi, N., Pa'Wan, F., Othman, N. A., \& Moksin, H. (2010). Factors influencing internal and external employability of employees. Business and Economics Journal, 11(1-10). 
Julie, Pallat. (2007). SPSS Survibal Manual: A step by step guide to data analysis using SPSS for Windows. Edited by 3. New York Open university press: McGraw Hill.

Karli, U. (2016). Adaptation and Validation of Self-Perceived Employability Scale: An Analysis of Sports Department Students and Graduates. Educational Research and Reviews, 11(8), 848-859.

Kiong, T. P., Cheng, E. H., Pei, O. S., \& Siew, H. K. (2019). Factors Influencing Employability of Chinese Graduates in Malaysia upon Returning to China. Asia Proceedings of Social Sciences, 4(1), $118-121$.

Mason, G., Williams, G., \& Cranmer, S. (2009). Employability skills initiatives in higher education: What effects do they have on graduate labor market outcomes? Education Economics, 17(1), 1-30.

McKenzie, K., \& Schweitzer, R (2001). Who succeeds at the university? Factors predicting academic performance in first year Australian university students. Higher Education Research and Development., 20(1), 21-33.

Michael, T. (2012). Graduate Employability: A Review of Conceptual and Empirical Themes. Higher Education Policy (international Association of Universities), 25, 407-431. https://doi.org/10.1057/ hep. 2011.26

Pitan, O. S., \& Atiku, S. O. (2017). Structural determinants of students' employability: Influence of career guidance activities. South African Journal of Education, 37(4).

Pheko, M. M., \& Molefhe, K. (2017). Addressing employability challenges: a framework for improving the employability of graduates in Botswana. International Journal of Adolescence and Youth, 22(4), 455-469.

Pool, L. D., \& Sewell, P. (2007). The key to employability: developing a practical model of graduate employability. Education+ Training.

Rivera, M. D. C. A., Gallego, L. V., Alvarez, M. A., Inchuaurtieta, A. M., Albizuri, I. E., \& de Eulate, C. Y. A. (2012). Perceived employability and competence development. Procedia-Social and Behavioral Sciences., 69, 1191-1197.

Qenani, E., MacDougall, N., \& Sexton, C. (2014). An empirical study of self-perceived employability: Improving the prospects for student employment success in an uncertain environment. Active Learning in Higher Education, 15(3), 199-213.

Rothwell, A., \& Arnold, J. (2007). Self-perceived employability: Development and validation of a scale. Personal review.

Rowe Anna D., \& Zegwaard Karsten E. (2017). Developing graduate employability skills and attributes: Curriculum enhancement through work-integrated Learning. Asia-Pacific Journal of Cooperative Education, Special Issue, 18(2), 87-99. http://www.abs.gov.au/AUSSTATS/abs@.nsf/Lookup/ C36857C8F381F427CA2575DF002DA755?opendocument

Rule, P. (2011). Bakhtin and Freiri: Dialogue dialects and boundary learning. Educational Philosophy and Theory, 43(9), 924-942.

Sachs, J., Rowe, A., \& Wilson, M. (2017). Good practice report - WIL. Report undertaken for the Office of Learning and Teaching. Retrieved from http://www.olt.gov.au/resource-good-practiceworkintegrated-learning

Semela, T. (2011). Breakneck expansion and quality assurance in Ethiopia higher education ideological rationales and economic impediments. Higher Education Policy, 24(3), 399-425.

Slameto. (2010). Belajar dan Faktor-faktor yang Mempengaruhinya. Jakarta: Rineka Cipta.

Suarta, I. M., Suwintana, I. K., Sudhana, I. F. P., \& Hariyanti, N. K. D. (2017, September). Employability skills required by the 21 st century workplace: A literature review of labor market demand. In International Conference on Technology and Vocational Teachers (ICTVT 2017). Atlantis Press.

Winkel, W. S., \& Sri Hastuti. (2004). BimbingandanKonseling di InstitusiPendidikan. Yogyakarta: Media Abadi.

Yamane, T. (1967). Statistics: An Introductory Analysis (2nd ed.). Harper and Row.

Yang, H., Cheung, C., \& Song, H. (2016). Enhancing the learning and employability of hospitality graduates in China. Journal of Hospitality, Leisure, Sport \& Tourism Education, 19, 85-96.

Yang, H., Ma, Y., Hu, P., \& He, G. (2018). A Study on Mediated Effects to Employability of Undergraduates in Different Groups: Job Intension and Extracurricular Activities. In 2018 2nd International Conference on Education, Economics and Management Research (ICEEMR 2018). Atlantis Press.

Yenew, A. M. (2019). Factors Associated with Women Unemployment in Ethiopia. International Journal of Theoretical and Applied Mathematics, 5(5), 68-73. https://doi.org/10.11648/j.ijtam.20190505.11

Yorke, M. (2010). Employability: Aligning the message, the medium and academic values. Journal of Teaching \& Learning for Graduate Employability, 1(1), 2-12. 
Zhong, L., Qian, Z., \& Wang, D. (2020). How does the servant supervisor influence the employability of postgraduates? Exploring the mechanisms of self-efficacy and academic engagement. Frontiers of Business Research in China, 14, 1-20. https://doi.org/10.1186/s11782-020-00079-1

Publisher's Note Springer Nature remains neutral with regard to jurisdictional claims in published maps and institutional affiliations. 